\title{
APLIKASI TRAP BARRIER SYSTEM (TBS) UNTUK MENANGGULANGI HAMA TIKUS PADA PERTANIAN PADI RAMAH LINGKUNGAN DI SUBAK TIMBUL DESA GADUNG SARI KECAMATAN SELEMADEG TIMUR KABUPATEN TABANAN BALI
}

\author{
I N. Ardika ${ }^{1}$ dan N.N. Darmiati ${ }^{2}$
}

\begin{abstract}
ABSTRAK
Kegiatan pengabdian kepada masyarakat ini bertujuan untuk mengaplikasikan Trap Barier System (TBS) untuk menanggulagi hama tikus sawah pada pertanian padi ramah lingkungan di Subak Timbul Desa Gadung Sari Kecamatan Selemadeg Timur Kabupaten Tabanan Bali.Metode yang diterapkan dalam pemberdayaan masyarakat pada kegiatan Ipteks bagi Wilayah (IbW) ini adalah: (1) Koordinasi dan komunikasi secara partisipasif dengan kelompok tani (subak) pengelola pertanian padi ramah lingkungan untuk merumuskan program mulai dari perencanaan, operasional dan evaluasi; (2) Penyuluhan untuk membangun persepsi dan pemahaman masyarakat mengenai inovasi program yang diterapkan; (3) Pelatihan mengenai terapan ipeks yang diaplikasi bagi masyarakat; (4) Pendampingan yaitu pertemuan secara berkala dan berkelanjutan antara pendamping dengan masyarakat sasaran hingga ipteks yang diaplikasikankan dapat dilaksanakan secara tepat.Hasil yang diperoleh menunjukkan bahwa kegiatan ipteks penanggulangan hama tikus melalui program IbW Desa Gadung Sari Kecamatan Selemadeg Timur Kabupaten Tabanan Bali dapat berlangsung dengan baik yang ditunjukkan dengan adanya partisipasi aktif dan daya adopsi ipteks yang tinggi. Partisipasi aktif anggota subak dalam seluruh kegiatan teknologi penanggulangan hama tikus cukup tinggi yakni sebesar 60 $95 \%$. Serangan tikus sawah dapat terjadi pada lokasi yang dekat dengan tepi pemukiman penduduk, tegalan, dan lingkungan yang kurang baik.
\end{abstract}

Kata Kunci: tikus, pertanian, subak.

\begin{abstract}
Community service activities is intended to apply Trap Barrier System (TBS) to eradicate rat in rice agriculture sustainable Subak Timbul, Gadung Sari Village, District of Eastern Selemadeg, Tabanan Regency, Bali. The methods used in community development in Science and Technology Activities for the Region ( $\mathrm{IbW}$ ) is: (1) Coordination and communication are participatory with farmers' groups (Subak) ecofriendly rice farming managers to formulate a program from the planning, operational and evaluation; (2) Extension to build public perception and understanding of the innovation programs implemented; (3) Training in applied technology that applied for the community; (4) Assistance is meeting regularly and sustainably among companion with target communities to applicated and technology that are in place.The results obtained showed that the science and technology activities to eradicate rat through IbW program in Gadung Sari Village, District of Eastern Selemadeg Tabanan Regency, Bali could take place as indicated by the active participation and adoption of science and technology are high. Active participation in all activities of the members of Subak rodent pest prevention technology is quite high, amounting to $60-95 \%$. Field mice attacks can occur at locations close to the edge of the settlement, moor, and the unfavorable environment.
\end{abstract}

Keywords: rat, farming, subak.

\footnotetext{
${ }^{1}$ Staf Pengajar Fakultas Peternakan Universitas Udayana, ardika@unud.ac.id

${ }^{2}$ Staf Pengajar Fakultas Pertanian Universitas Udayana
} 
Aplikasi Trap Barrier System (TBS) Untuk Menanggulangi Hama Tikus Pada Pertanian Padi Ramah Lingkungan Di Subak Timbul Desa Gadung Sari Kecamatan Selemadeg Timur Kabupaten Tabanan Bali

\section{PENDAHULUAN}

Struktur penduduk menurut mata pencaharian di Desa Gadung Sari Kecamatan Selemadeg Timur Kabupaten Tabanan menunjukkan bahwa sebagian besar penduduk menggantungkan sumber kehidupannya di sektor pertanian ( $82 \%$ ), sektor lain yang menonjol dalam penyerapan tenaga kerja adalah perdagangan (4.\%), sektor industri rumah tangga dan pengolahan $(2,3 \%)$, sektor jasa $(0,8 \%)$ dan sektor lainnya seperti pegawai negeri, karyawan swata dari berbagai sektor $(1,6 \%)$. Angka tersebut mengindikasikan bahwa sektor pertanian merupakan bidang startegis sehingga perlu medapatkan prioritas. Usaha tani merupakan bidang usaha di hulu, diharapkan dengan berkembangnya sistem pertanian yang berwawasan agribisnis dapat menstimulasi bidang jasa dan usaha lainnya di hilir. Komoditas unggulan dari subsektor pertanian tanaman pangan adalah padi. Produksi padi kawasan ini mencapai 2.891 ton pada tahun 2012. Persoalan yang dijumpai terkait dengan sektor pertanian tanaman pangan diantaranya padi sebagai komoditas unggulan wilayah belum memberikan pendapatan yang memadai bagi petani. Untuk meningkatkan pendapatan petani Pemerintah Kabupaten Tabanan mengembangkan program beras sehat yaitu beras yang diproduksi dengan menerapkan pertanian atau memanfaatkan input kimiawi yang sangat minim.

Di Desa Gadung Sari terdapat subak (kelompok tani) bernama Subak Timbul dengan luas lahan mencapai 45 ha telah siap untuk mengaplikasikan teknologi pertanian padi ramah lingkungan dalam memproduksi beras sehat tersebut. Dengan menjadikan subak tersebut sebagai pilot proyek diharapkan akan dapat merangasang subak lainnya mengaplikasikan pertanian beras sehat tersebut. Persoalan yang sangat urgen pada subak tersebut adalah serangan hama tikus yang sangat masif menyebabkan gagal panen. Serangan hama tikus pada Subak Timbul pada tahun sebelumnya adalah cukup tinggi sampai mencapai diatas $25 \%$. Untuk menanggulangi hama tikus tersebut berbagai cara bisa ditempuh yaitu penggunakan bahan kimiawi termasuk racun akut, anti koagulan dan agens biologis. Bahan kimia tersebut secara ekonomis jelas memberikan pengaruh dalam segi pembiayaan dan jika digunakan secara tidak tepat dapat membunuh hewan bukan sasaran serta menyebabkan pengaruh negatif terhadap kesehatan manusia dan lingkungan (Mashur, 2009).

Metode Trap Barrier System (TBS) atau sistem bubu perangkap yang dikelola secara berkelompok sebagai metode non kimiawi untuk mengendalikan hama tikus pada penanaman padi di lahan sawah beririgasi cukup efektif. Metode ini telah diuji dan terbukti efektif dalam menurunkan kerusakan tikus di lahan sawah beririgasi di Indonesia. Bagian utama dari sistem ini adalah petak Trap Barrier System yang didalamnya terdapat perangkap. Di sekelilingnya dibuat parit yang diisi air dan lubang masuk tikus dimana pada setiap lubang masuk dipasang bubu perangkap yang dapat menangkap tikus dalam jumlah yang banyak. Tanaman perangkap yang telah terbukti efektif sampai saat ini adalah tanaman perangkap yang ditanam 2-3 minggu lebih awal dari penanaman padi di sekitarnya (Ngatimin dan Saranga, 2015). Bertitiktolak dari persoalan diatas perlu adanya aplikasi teknologi perangkap tikus yang ramah lingkungan. Agar program ini berjalan efektif sangat diperlukan adanya pendampingan Perguruan Tinggi. Fungsi dari pendamping adalah sebagai inisiator, motivator, fasilitator, inovator dan komunikator dalam pembangunan secara luas. Dalam konteks ini, pendampingan dilakukan oleh tim Ipteks bagi Wilayah Desa Gadung Sari.

\section{METODE PELAKSANAAN}

Metode yang diterapkan dalam pemberdayaan masyarakat pada kegiatan IbW ini adalah sebagai berikut: (1) Penyuluhan untuk membangun persepsi dan pemahaman masyarakat mengenai inovasi atau program yang diterapkan, (2) Pelatihan mengenai terapan ipeks yang diaplikasi bagi masyarakat, dan (3) Pendampingan yaitu pertemuan secara berkala dan berkelanjutan antara pendamping dengan masyarakat sasaran hingga ipteks yang diaplikasikan dapat dilaksanakan secara tepat oleh masyarakat.

VOLUME 17 NOMOR 1, JANUARI 2018 | 87 
Pelaksananan kegiatan alih teknologi Trap Barrier System untuk pengendalian hama tikus pada pertanian padi ramah lingkungan adalah sebagai berikut :

(1) Kordinasi dan komunikasi secara partisipasif dengan anggota subak untuk merumuskan program mulai dari perencanaan, operasional dan evaluasi

(2) Penyuluhan tentang pentingnya pengendalian hama tikus dan aplikasi teknologi Trap Barrier System (TBS) pada pertanian padi ramah lingkungan.

(3) Pelatihan pengolahan tanah sampai penanaman padi.

(4) Pembuatan demplot dan pendampingan pemasangan petak Trap Barrier System melalui bimbingan teknis secara berkala dengan anggota subak dan pemberian konsultasi menyangkut solusi dari berbagai persoalan terkait dengan aplikasi teknologi tersebut.

\section{HASIL DAN PEMBAHASAN}

Kegiatan pengabdian kepada masyarakat ini dilaksanakan di Subak Timbul, Desa Gunung Sari, Kecamatan Selemadeg Timur, Kabupaten Tabanan. Propinsi Bali. Pendampingan dilakukan pada 20 orang anggota subak yang sekaligus mengikuti Sekolah Lapang Pertanian Padi Ramah Lingkungan selama 3 bulan mulai bulan Juli sampai bulan September 2016. Desiminasi teknologi dilaksanakan melalui kegiatan sosialisasi dan persiapan materi, kegiatan penyuluhan dan pemutaran video TBS, selama 1 hari yang dipusatkan di Balai Subak Timbul. Kegiatan pendampingan melalui pembuatan demoplot di areal sawah milik anggota subak selama satu bulan. Ipteks yang aplikasikan pada subak Timbul adalah Trap Barrier System (TBS).

Trap Barier System (TBS) merupakan salah satu teknik pengendalian tikus sawah yang dapat menangkap tikus dalam jumlah banyak dan terus menerus, terutama di daerah endemik tikus dengan tingkat populasi tinggi dan tanam serempak (Anggara, 2014). TBS terdiri atas tanaman padi sebagai perangkap atau umpan tikus, pagar dari terpal, dan bubu perangkap sebagai alat penangkap tikus.

Tanaman padi sebagai perangkap berukuran $20 \mathrm{mx} 20 \mathrm{~m}$, atau disesuaikan dengan petak/pematang sawah, ditanam 2-3 minggu lebih awal daripada tanaman padi sekelilingnya dapat mengamankan pertanaman padi disekitarnya seluas 15 ha. Tanam lebih awal maksudnya untuk menarik tikus disekitarnya untuk mendatangi tanaman perangkap. Pagar dari terpal dipasang dengan tinggi 60-70 $\mathrm{cm}$ mengelilingi tanaman perangkap. Pagar terpal ditegakkan dengan ajir bambu dengan jarak $1 \mathrm{~m}$ dan ujung bawah terendam air dalam parit. Parit lebarnya 40-50 $\mathrm{cm}$ dan diusahakan selalu berisi air agar tikus tidak melubangi pagar. Parit selalu dalam keadaan bersih (tidak ada gulma) supaya tikus tidak dapat memanjat. Bubu perangkap dibuat dari ram kawat, berbentuk kotak berukuran 40x20x20 cm, dilengkapi corong/pintu masuk tikus dibagian depan dan pintu belakang untuk mengeluarkan tikus. Untuk mengarahkan tikus supaya masuk ke pintu bubu difasilitasi dengan dibuatkan jembatan tikus yang terbuat dari gundukan tanah yang menghubungkan antara pematang parit menuju ke pintu bubu perangkap (Gambar 3 dan 4).

Demoplot TBS dilakukan pada empat lokasi yang berada di areal pematang sawah milik anggota subak yang masing-masing luasnya kurang lebih 3 are. Pemilihan lokasi demoplot berdasarkan serangan hama tikus pada periode tanam sebelumnya. 
Aplikasi Trap Barrier System (TBS) Untuk Menanggulangi Hama Tikus Pada Pertanian Padi Ramah Lingkungan Di Subak Timbul Desa Gadung Sari Kecamatan Selemadeg Timur Kabupaten Tabanan Bali

Tabel 1. Partisipasi Anggota Subak dalam Kegiatan Trap Barrier System (TBS)

\begin{tabular}{|c|c|c|c|}
\hline \multirow[t]{2}{*}{ No } & \multirow[t]{2}{*}{ Kegiatan } & \multicolumn{2}{|c|}{ Anggota Subak } \\
\hline & & Jumlah & Persentase (\%) \\
\hline A & Penyuluhan dan Pemutaran video TBS & & \\
\hline 1 & Kehadiran & 20 & 100 \\
\hline 2 & Keaktipan mengungkapkan permaalahan & 12 & 60 \\
\hline $\mathrm{B}$ & Kegiatan Demoplot TBS (4 demoplot) & & \\
\hline 1 & Pembuatan parit dan penanaman padi & 20 & 100 \\
\hline 2 & Pemasangan TBS (ajir, terpal dan bubu) & 19 & 95,5 \\
\hline
\end{tabular}

Pelaksanaan penanggulangan tikus dengan TBS pada anggota subak dapat berjalan dengan baik dimana kegiatan penyuluhan dan pemutaran video TBS (Gambar 1) yang dilakukan di Balai Subak diikuti oleh seluruh anggota $(100 \%)$. Begitu pula terjadi komunikasi dua arah yang sangat baik yang ditunjukkan oleh anggota subak yang mengungkapkan permasalahan $(60 \%)$ terkait dengan penanggulangan hama tikus tersebut (Tabel 1). Selanjutnya pada kegiatan demoplot aplikasi pembuatan TBS juga berjalan dengan baik terutama dalam pembuatan parit yang dilanjutkan dengan penanaman padi (Gambar 2) dengan sistem jajar legowo kehadirannya 100\%. Hal yang sama juga ditunjukkan oleh anggota subak pada kegiatan pemasangan ajir, terpal dan bubu perangkap $(95,5 \%)$.

Tabel 2. Jumlah Tikus Masuk Perangkap dan Serangan Tikus dengan Radius Satu Area Sawah

\begin{tabular}{|c|c|c|c|}
\hline No & Demoplot & $\begin{array}{c}\text { Jumlah Tikus yang Masuk Bubu } \\
\text { Perangkap (ekor) }\end{array}$ & $\begin{array}{c}\text { Luas Serangan } \\
\text { Tikus }\end{array}$ \\
\hline 1 & I & 14 & Ringan \\
\hline 2 & II & 6 & Tidak ada \\
\hline 3 & III & 1 & Tidak ada \\
\hline 4 & IV & 3 & Tidak ada \\
\hline
\end{tabular}

Tabel 2 menunjukkan bahwa jumlah tikus yang masuk bubu perangkap tertinggi pada lokasi demoplot I (58,33\%) diikuti oleh demoplot II (25\%), IV (12,5\%) dan III (4,17\%). Serangan tikus terjadi hanya pada lokasi demoplot I yang termasuk serangan ringan $(<10 \%$ dari areal sawah pada demoplot I). Tingginya jumlah hama tikus dan serangan tikus pada demoplot I disebabkan oleh lokasi demoplot yang dekat dengan pemukiman penduduk, saluran irigasi dan tegalan. Pada ekositem sawah irigasi teknis ada lima habitat utama tikus sawah yaitu tepi kampung, tanggul irigasi, jalan sawah, parit sawah dan tengah sawah. Habitat tepi kampung merupakan habitat yang paling disukai tikus sawah. Habitat tepi kampung merupakan tujuan tikus migrasi pada periode bera untuk memperoleh pakan alternatif dan tempat berlindung sementara (Anggara, 2014). Selanjutnya dinyatakan bahwa pengaturan waktu tanam dan panen juga berpengaruh terhadap serangan tikus. Pengaturan waktu tanam bertujuan agar periode generatif padi bersamaan waktunya. Tanaman yang bunting lebih awal akan mendapatkan serangan tikus paling berat. Ditambahkan pula oleh Ngatimin dan Saranga (2015) serangan hama tikus paling besar terjadi setelah pembentukan bakal malai padi. Bakal malai merupakan makanan yang sangat disukai oleh tikus dan pada saat itu banyak tersedia makanan. Penanaman padi dengan jarak yang lebih longgar/jajar legowo akan membuat lingkungan lebih terbuka yang kurang disukai tikus. Kondisi lingkungan yang bersih dan terang cendrung kurang disukai tikus kemungkinan tikus merasa lebih terancam oleh musuh alami. Hal ini diperlihatkan oleh serangan tikus sawah yang selalu dimulai dari tengah petak sawah dan biasanya menyisakan pertanaman dekat pematang.

Keberhasilan adopsi penanggulangan hama tikus dengan metode Trap Barrier System memberikan manfaat bagi anggota subak baik pada saat ini maupun mendatang. Dengan metode ini anggota subak akan terus mencoba pada periode penanaman padi mendatang agar serangan hama tikus dapat ditanggulangi.

VOLUME 17 NOMOR 1, JANUARI 2018 | 89 


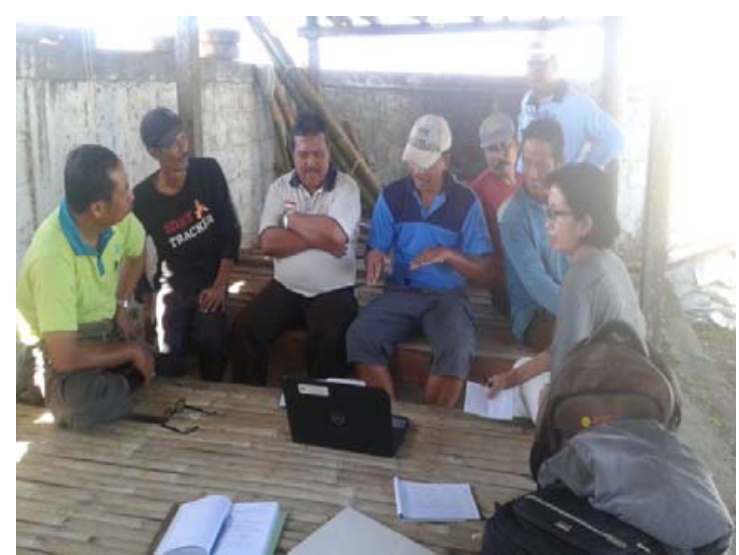

Gambar 1. Pemutaran Video TBS

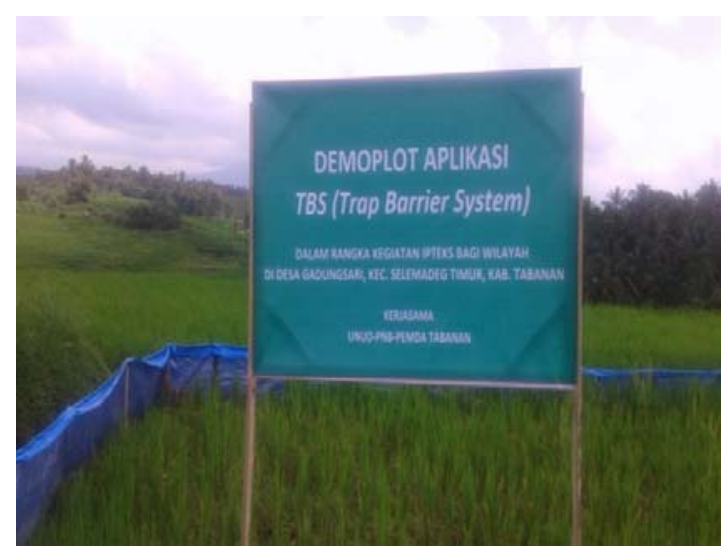

Gambar 3. Demoplot TBS

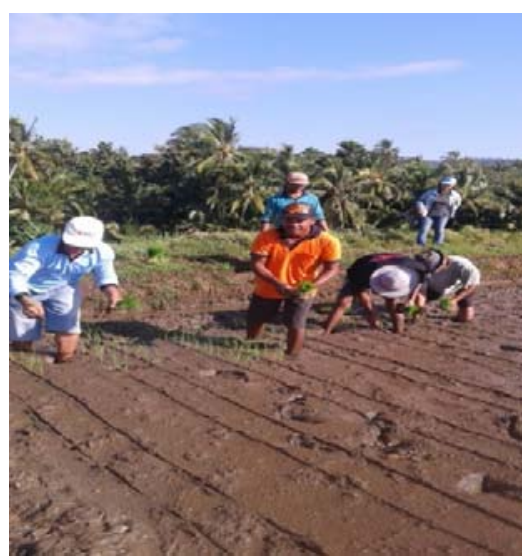

Gambar 2. Penanaman Bibit Padi demoplot

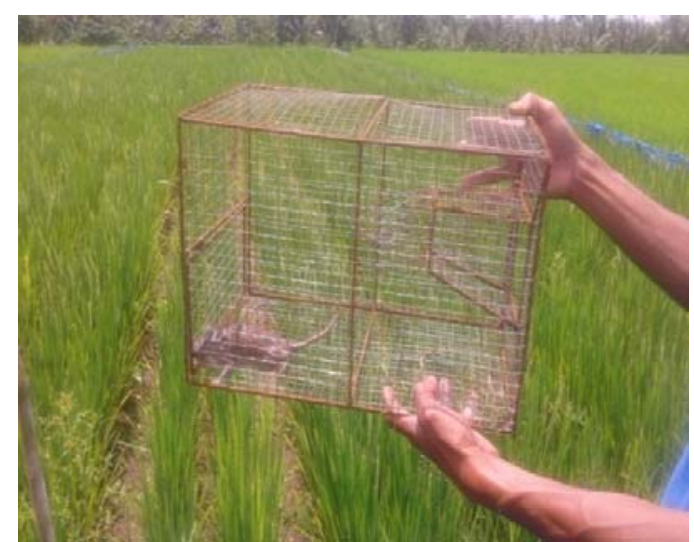

Gambar 4. Tikus yang masuk perangkap

\section{KESIMPULAN DAN SARAN}

Dari uraian diatas dapat disimpulkan sebagai dibawah ini:

1. Kegiatan ipteks penanggulanan hama tikus melalui program IbW Desa Gadung Sari Kecamatan Selemadeg Timur Kabupaten Tabanan Bali dapat berlangsung dengan baik yang ditunjukkan dengan adanya partisipasi aktif dan daya adopsi ipteks yang tinggi.

2. Partisipasi aktif anggota subak dalam seluruh kegiatan teknologi penanggulangan hama tikus cukup tinggi yakni sebesar $60-95,5 \%$.

3. Serangan tikus sawah dapat terjadi pada lokasi yang dekat dengan tepi pemukiman penduduk, tegalan, dan lingkungan yang kurang. 
Aplikasi Trap Barrier System (TBS) Untuk Menanggulangi Hama Tikus Pada Pertanian Padi Ramah Lingkungan Di Subak Timbul Desa Gadung Sari Kecamatan Selemadeg Timur Kabupaten Tabanan Bali

\section{UCAPAN TERIMAKASIH}

Penulis menyampaikan terima kasih yang sebesar-besarnya kepada Direktorat Riset dan Pengabdian pada Masyarakat Kemenristek Dikti atas dana yang diberikan, Ketua Lembaga Pengabdian kepada Masyarakat Universitas Udayana serta Subak Timbul yang telah membantu kelancaran kegiatan ini.

\section{DAFTAR PUSTAKA}

Anggara, A.W. 2014. Hama tikus sawah dan cara penanggulangannya. http://www.artikelpadi.com/ Hama tikus sawah dan cara penanggulangannya. Diakses tanggal 17 Nopember 2016.

Arlina dan Anthoni. 2014. Cara mengatasi tikus sawah dengan TBS dan LTBS. Badan Penelitian dan Pengembangan Pertanian, Balai Besar Penelitian Tanaman Padi. Diakses tanggal 17 Nopember 2016.

Mashur. 2009. System bubu perangkap teknologi ramah lingkungan pengendalian tikus. Diakses tanggal 17 Nopember 2016.

Ngatimin, S.N.A. dan P. Saranga. 2015. Pengendalian tikus sawah Rattus argentiventer Robb \& Kloss (Rodentia:Muridae) dengan system perangkap bubu linier (SPBL) pada tiga zona habitat tikus di Kabupaten Sulawesi Selatan. Jurusan Hama dan Penyakit Tumbuhan Fak. Pertanian UNHAS Makasar. Diakses tanggal 17 Nopember 2016. 